Cinémas

Revue d'études cinématographiques

Journal of Film Studies

\title{
André Bazin, What is Cinema?, translated by Timothy Barnard, Montréal, Caboose, 2009.
}

\section{Dudley Andrew et Prakash Younger}

Volume 20, numéro 1, automne 2009

Cinéma et oralité. Le bonimenteur et ses avatars

URI : https://id.erudit.org/iderudit/039279ar

DOI : https://doi.org/10.7202/039279ar

Aller au sommaire du numéro

Éditeur(s)

Cinémas

ISSN

1181-6945 (imprimé)

1705-6500 (numérique)

Découvrir la revue

Citer ce compte rendu

Andrew, D. \& Younger, P. (2009). Compte rendu de [André Bazin, What is

Cinema?, translated by Timothy Barnard, Montréal, Caboose, 2009.] Cinémas,

20(1), 205-210. https://doi.org/10.7202/039279ar d'utilisation que vous pouvez consulter en ligne.

https://apropos.erudit.org/fr/usagers/politique-dutilisation/ 
André Bazin, What is Cinema?, translated by Timothy Barnard, Montréal, Caboose, 2009.

In one of the boldest moves ever seen in Anglophone cinema studies, Timothy Barnard, the director of Caboose, a new Montreal-based publishing house, has bucked the University of California's authority over André Bazin's What is Cinema? to present a selection of his own translations of these landmark essays in an elegant one-volume edition. Taking advantage of Canada's more reasonable fifty-year limit on author's rights (rather than the seventy-and counting - that applies in most other places), he launched his rocket just after midnight last New Year, the minute it became legal. Feeling ambushed and poached upon, California and the French may well pursue this renegade edition of what are arguably the most valuable of all Film Studies texts. Meanwhile, anyone who cares about Bazin or his titular question can applaud with glee, for we now can routinely give him a second reading, something that never fails to pay off. If the publication's carnivalesque rebuff to corporate control of "intellectual property" will amuse Film Studies scholars, we should not fail to recognize the far more important provocation in Barnard's claim that this is "the first accurate and reliable English translation of these essays to appear." If Film Studies as the discipline we know today began with Bazin, and if its development has in some sense always been governed by that beginning-even, and perhaps most strongly, when his ideas have been repudiated - then these new translations offer a rare platform on which to take stock of our foundations. Is it possible that we never got Bazin right in the first place? These new translations challenge us to jettison the received wisdom and take a fresh look at what he actually wrote. Those of us who own the French edition will be sent back to the original again 
and again so as to try to resolve the frequent discrepancies between Hugh Gray's forty-year-old version and Tim Barnard's, hot off the press. Reading even a few cunning sentences in the French original of "Editing Prohibited" (known heretofore as "The Virtues and Limitations of Montage") sets off vibrations among the three versions that wake us up to the micro-nuances and macro-concepts we would otherwise have been oblivious to.

In fact, however, despite their matching titles, the two English versions don't fully overlap. Bazin's original four slim volumes consist of sixty-three selections. Hugh Gray chose twenty-six for the two volumes that California brought out in 1967 and 1971. Barnard gives us half as many, ten taken from selections that also appear in Gray, but three that Gray had passed over: the lengthy, indispensable essay on William Wyler, plus the delightful "Monsieur Hulot and Time" and "On Jean Painlevé." A further discrepancy follows from Barnard's decision to translate five of the essays not from Qu'est-ce que le cinéma? but from the original versions as they appeared in Esprit and elsewhere. Why did he nullify Bazin's effort to bring his own work into a form that endures? Barnard's answer that "some of the discussions later excised [are] worthy of preservation" is not satisfactory, for it ought to apply to all thirteen. (What a shock to film theory would be Bazin's initial and wilder "Ontology" essay, first drafted when he was 26.) Did he take the essays as he found them in Bazin's volume one ("Ontologie et Langage") because he knew Bazin had monitored this right up to the point of reading page proofs? Perhaps Barnard surmises that, sick as he was in 1958, Bazin may not have reworked the five pieces that were typeset posthumously. Did someone perform the operation of "excision" that Barnard now reverses? But Jacques Rivette is adamant when introducing volume four (on neo-realism) that, while the editors chose and organized the table of contents for this particular volume, they would never take it upon themselves to rework the master's prose. (Barnard could have caught Rivette out here, since his "The Italian School of the Liberation," unaltered from Esprit 1948, is a bit longer than the French version Rivette took, presumably whole cloth, to the printers in 1962.) The answer is probably more mundane and 
overdetermined; in 2008, Canadian rights were clear only for volume one. Barnard didn't want to wait, even a little while, to dip into the volumes on adaptations and neo-realism.

We're glad he took this route, not only because it enlivens Bazin right now, but also because these early editions of five such crucial essays let us speculate about Bazin's intentions in altering them in 1958. Barnard was probably drawn to the originals because of the wonderful and inveterate philologue he is. Look at the precious notes he has developed through fastidious library research. This is a scholar's edition, or the beginnings of one. As the foreword points out, only twice does he venture into the etymological labyrinth of key terms ("découpage" and "montage"), and twice he elaborates on intellectual history, linking Bazin tellingly to Malraux and to Kracauer (an astounding and ingenious intuition). These adumbrations, running on for pages, are worthy of full articles, perhaps an entire book, one that we urge Barnard to put together. Placed here, these and all the other notes slow our reading of Bazin and make us question common interpretations. Nothing could be healthier.

Of course translation is itself always interpretation; this we are struck with repeatedly as we hear a different voice coming from the depths of Bazin's corpus, different from the Bazin we have listened to for forty years. Readers fluent in French have frequently complained that Hugh Gray's translations tend to emphasize, through their serene and elegant tone as much as their rendering of crucial phrases, the religious sensibility sublimated in Bazin's phenomenology. In Gray's idiom the photograph's ontological connection to reality is something that must be respected, something that one must put one's faith in, and one can see how those who don't know the French might thereby accuse Bazin of a form of mysticism, while those who do know the French might instead blame Gray. Gray loses the quasiBenjaminian Bazin, whose often droll and always dialectical analyses of cultural phenomena are set in specific social and historical contexts, not, as Gray might have it, in the eternity of aesthetic achievement; one cannot, for example, imagine Gray's Bazin describing the cinema as an artistic technology that 
corresponds to "the accession to power by the masses" ("l'accession des masses au pouvoir," our translation), a bluntly militant phrase from "Ladaptation, ou le cinéma comme digeste" (Bazin 1948, p. 37). Given this long-standing complaint against Gray, one could expect that these "accurate and reliable" translations might attempt to restore and carefully synthesize the militant Bazin with whatever measure of the reverent Bazin the standard of accuracy requires the translator to retain, with the result being a richer, more contradictory thinker. But this is not, as far as one can tell, Barnard's approach at all. Rather than attempt to balance or synthesize the possible interpretations of what, for example, Bazin means by "reality," Barnard maintains a firm agnosticism regarding such questions since (and in accordance with a philologue's strict historicism) it is quite possible reality meant different things to Bazin at different times and in different contexts.

Barnard therefore endeavours to produce the most literal and, in a sense, the most conservative or neutral rendering, the one that best suits the argument that he sees Bazin to be fashioning in a given essay. Contrast, for example, Gray's and Barnard's renderings of one of the most difficult yet unforgettable sentences in "Ontologie de l'image photographique":

Sur la photographie, image naturelle d'un monde que nous ne savions ou ne pouvions voir, la nature enfin fait plus que d'imiter l'art: elle imite l'artiste (Bazin).

By the power of photography, the natural image of a world that we neither know nor can see, nature at last does more than imitate art: she imitates the artist (Gray).

In the photograph, a natural image of a world we are no longer able to see, nature finally does more than imitate art: it imitates the artist (Barnard).

Slight as they may seem, the differences between the two translations are quite significant. Each takes what in the French is in l'imparfait de l'indicatif, and might most simply be read as - "A world we did not know how to see and hence were unable to see" - (before the art of the photograph taught how to see it) - and either transposes it into another tense, the present 
indicative ("a world we neither know nor can see"), or conflates two verbs (savoir - to know how to-and pouvoir - to be able to) while transposing the object world into the past ("a world we are no longer able to see"). By doing this Barnard reinforces the sentence's connection with the essay's opening argument concerning the primordial function of any visual art (i.e. to redeem the mortality of the world by preserving its appearance through resemblance). Gray's more poetic transposition of the phrase into the present tense, on the other hand, makes the revelatory power of the photograph more hyperbolic but also more confusing - it almost suggests that we still "neither know nor can see" the world in question (despite the natural image of it revealed in the photograph) and thus comes close to denying the primordial function that Barnard takes pains to emphasize (by implying that the world in question is inherently "unknown and invisible").

Rather than attempt to answer the questions posed by ambiguous phrases with interpretive adjectives or paraphrase, Barnard's mission is to strip the questions in each essay bare for others to address; if, and in contrast to Gray, there does not appear to be any overriding interpretation of Bazin's thought that Barnard believes in, his agnosticism cannot be separated from an almost anachronistic faith in the community of critical interlocutors who, he hopes, will eagerly take up the questions he has exposed. This tender and chivalrous sentiment is made quite clear in the foreword and reinforced by the painstaking translator's notes, certain of which will undoubtedly become famous in their own right. The twenty-page note on "découpage" presents a comprehensive genealogy of the term's use from France in the 1920s up to a refutation of David Bordwell today and clearly demonstrates that, while for Bazin and his followers at Cahiers du cinéma, it refers to the disposition of scenes, profilmic space, blocking, camera angles, camera movement and other factors that come into play at the stages of scripting and shooting, it has consistently been mistranslated in English as "editing" or "cutting" and thus misrepresented as a concept in English-language film scholarship. Among other things, Barnard's trenchant dismissal of any equation of the 
term with editing allows us to recognize that découpage has an integral connection with what the early 1950s Cahiers critics called mise en scène and could often serve as a synonym for an auteur's unique style. He establishes here the legacy of Bazin to his disciples, and to us. Only one example of the many surprises this fastidious translation delivers.

Dudley Andrew and Prakash Younger

\author{
Yale University and \\ Trinity College
}

\title{
BIBLIOGRAPHICAL REFERENCES
}

Bazin 1948: André Bazin, "L'adaptation, ou le cinéma comme digeste," Esprit, no. 16,1948 , pp. $32-40$

Bazin 1962: André Bazin, Qu'est-ce que le cinéma?, 4 volumes, Paris, Cerf, 19581962.

Bazin 1967: André Bazin, What Is Cinema?, translated from French by Hugh Gray, Berkeley, University of California Press, 1967.

Bazin 1971: André Bazin, What Is Cinema? II, translated from French by Hugh Gray, Berkeley, University of California Press, 1971.

Bazin 2009: André Bazin, What is Cinema?, translated from French by Timothy Barnard, Montréal, Caboose, 2009. 